\title{
Parenting Model on Children's Learning Activities at Home during the Covid-19 Pandemic: A Case Study
}

\author{
Hendrikus Midun ${ }^{1}$, Widdy H. F. Rorimpandey ${ }^{2}$, Fidelia Mamuaja ${ }^{3}$, Fientje Oentoe ${ }^{4}$ \\ Universitas Katolik Indonesia Santu Paulus Ruteng ${ }^{1}$, Universitas Negeri Manado, Indonesia ${ }^{2}$ \\ \{hendrik.m2002@gmail.com $\left.{ }^{1}\right\}$
}

\begin{abstract}
One of the educational problems during the Covid-19 pandemic is the role of parents in guiding children to learn. Their role is to determine the success of students' learning, especially elementary school students. This study aims to describe the parenting model on student learning activities during the pandemic. This study was conducted at the Santa Theresa SDK, Paremei, Manado. This study uses a qualitative approach. Data collection methods are structured interviews and data analysis techniques using descriptive qualitative. The results of the study reveal that during the pandemic, parents who educate children with democratic parenting are more likely than authoritarian and permissive parenting styles. The parenting model applied by parents in the family is relatively consistent. However, the consistency of the use of parenting without a thorough assessment of its effectiveness on student learning outcomes at school. These findings have implications for the practice of tutoring for children and recommendations for future research.
\end{abstract}

Keywords: Parenting model, learn from home, Covid-19 pandemic, learning activities

\section{Introduction}

During the Covid-19 Pandemic, the Minister of Education and Culture of the Republic of Indonesia made a policy regarding the implementation of distance education or online learning. Previously, online learning was only an option for educational institutions or teachers, but during the pandemic, online learning is a must for every educational institution. Online learning as a preference for the best learning strategy during the Covid-19 pandemic [1] demands the optimal role of parents. Parents should act as primary educators and caregivers for their children. In the context of the advancement of internet technology, parents act as peacemakers between generations of internet civilization [2].

Previous studies revealed that the family has contributed significantly to social development and achievement of students. Study conducted by Sudiapermana, et al [3], involving 121 families with children in the fifth grade of elementary school, has reported that the atmosphere of intimacy created in the family, the ability of families to adapt to changes and the aspirations of parents in children's education are factors which has a positive effect on the success and achievement of student learning at school. A study by Midun [4] has concluded that the family is the best place for seeding, growth, development and appreciation of the character values of students.

During the Covid-19 pandemic, families who have not optimally carried out their educational function will experience confusion, worry, anxiety, stress and fear of facing various 
challenges experienced during the pandemic, especially related to parenting children to study at home [5] [6]. This condition can reduce the productivity of education, both in the implementation of learning, study hours, services and the work of graduates [7] [8]. The decline in educational productivity during the pandemic was caused by students, teachers and educational institutions not yet ready to carry out the transformation of education from offline to online [9] [10] [11]. In addition, parents also have not carried out the function of education optimally, especially parents who do not have sufficient computer-internet literacy [12] [13].

Parental skills to guide children to study at home can encourage quality learning experiences for children (during the pandemic) and have a positive effect on student academic achievement [14].This study aims to describe the parenting model in children's learning activities during the Covid-19 pandemic and the implications for character building and student learning motivation.

\subsection{Literature Review}

\section{Parenting Patterns and Children's Learning Activities During the Pandemic}

At first, parenting was understood as the ability of parents to provide time, attention and support for children so that children can grow and develop well, both physically, mentally (morally), and socially [15]. However, in further developments, the concept of parenting is broader than the willingness (time) of parents to educate their children. Parenting is related to the educational function that parents have in the family. Therefore, parenting is related to the approaches, methods and strategies used by parents in educating their children.

Parenting models (approaches, methods, strategies) for children greatly affect the cognitive, mental, and social development of children. Research conducted by Christner, et al [16] revealed that many children experience stress when they study at home, not only because they cannot meet and play with their friends at school, but also because parents have not found the best way to guide them to learn. Therefore, democratic parenting can certainly reduce the level of stress experienced by children at home.

Furthermore, Christner, et al found that parents with high levels of stress had an impact on the various forms of violence they committed against their children during the pandemic. The relationship between children and parents, parenting style and social support are other factors that influence parental violence against children [17]. The violence that parents do to their children when they accompany their children to study is also triggered by the weakness of parents in digital internet literacy. The success of children (elementary school age) studying at home is also related to the skills of parents to accompany and train children to use digital technology (DT) devices to study (such as accessing learning resources, completing assignments and exams).

In relation to the use of digital technology, $\mathrm{Wu}$, et al [18] describe three roles of parents in guiding children in learning: 1) training children to use digital technology effectively; 2) identify digital technology content that is appropriate to the child's developmental level and learning problems they are experiencing; and 3) assisting and controlling children in using digital technology.

\section{Types of Parenting Patterns and Characteristics of Children}

In Indonesia, there are three fields of serious research on childcare, namely education, health and psychology. This was revealed in a meta-analysis study conducted by Kiling-Bunga, et al [19]. They have reviewed 94 articles and have identified education, health and psychology as fields of high-quality research on childcare. That means, empowering parents in childcare must be done collaboratively. Collaborative work (the three fields) produces various models or 
patterns of parenting in the family. In general, there are three patterns or models of parenting, namely authoritarian, permissive and democratic [20] [21].

According to Stewart and Koch as quoted by Aisyah [22] explained the character of each character. First, Authoritarian Parenting. This parenting style has traits such as parents using rigid rules, strict, punitive, lack of love and sympathy, forcing children to obey the values they believe to be true and tend to curb children's desires. Second, Permissive Parenting. The characteristics are that parents do not exercise strict control over their children and give freedom to children, more decisions are made by children than their parents. Third, democratic parenting. Democratic parenting has the following characteristics: children are given the opportunity to be independent and develop their internal control, parents acknowledge the existence of children, and children are involved in making decisions. These three parenting models are the basis for this research.

A study conducted by Sunarty and Dirawan [23] found that the type of parenting style affects children's independence, especially related to learning activities. Furthermore, Boediman and Desnawati [24] who conducted a study on 126 parents of children aged 3 and 6 years revealed that there is a positive relationship between parenting style and the development of children's emotional regulation. Specifically, Leijten, et al [25] examined the impact of parenting in the form of verbal reprimands. They have reported that parenting in the form of verbal reprimands can shape children's obedience.

The value of obedience possessed by each child is certainly not automatically experienced by all children at different age levels, depending on the characteristics, needs, abilities, background of the child's experience, and the pattern of parent-child relationships in the family. Reid, et al [26] mention the factors that support the parenting model in the family, namely emotional warmth, punitive discipline, anxiety, support for autonomy, permissive discipline and democratic discipline. However, regardless of the parenting model used, every parent wants each child to experience (positive) development in various aspects proportionally.

\section{Learning from Home and the role of Parental pedagogy}

Education during the pandemic by the tagline "learning from home" demands parental pedagogical responsibility. Although prior to the Covid-19 outbreak, many parents had succeeded in educating their children at home, this fact cannot be generalized to the entire parent population [27]. The Indonesian government's policy to study from home during the pandemic is an order for all parents to "return" to their role as important educators for their children.

As pedagogues for children, parents must act as designers, managers, and learning facilitators for their children at home [28]. As learning designers, parents must be able to design daily activities with educational motifs. Parents need to be with their children in every daily activity at home, such as handwork, watching TV or YouTube news, searching and finding learning resources, reading books or Google, completing assignments, discussing problems, etc. As learning managers, parents need to create learning conditions (physical and social) that allow all learning activities to be carried out effectively and fun.

Furthermore, as learning facilitators for children, parents try to make learning easier for children. Parents must be active and creative in providing and guiding their children to find learning resources, providing consultancy for solving learning problems, growing and developing independent learning abilities for their children. 


\section{Research Methods}

\subsection{Approach and Type of the Study}

This study uses a qualitative approach through case studies. Cresswell [29] states that qualitative research is carried out in a natural environment (natural setting), has multiple sources of data, and researcher is the key instrument. The type of research is descriptive qualitative. By using this type of qualitative descriptive research, researchers want to describe events, facts, circumstances, and phenomena that occur during the research. The facts and events were obtained from the informants when they were observed and interviewed. Through case studies, this research focuses intensively on one particular object as a case. Thus, this study in depth describes the cases experienced by individuals in everyday life, especially the parenting patterns of parents towards children during the learning period from home.

\subsection{Research Locations and Subjects}

This study was conducted at the SDK Santa Theresia Parepei, Remboken. District, Manado. This study was conducted from February to March 2021. The research subjects were all parents of third grade students at the SDK Santa Theresia Parepei, Remboken District, Manado.

\subsection{Data Source}

The source of data in this study is primary data, namely data obtained directly from the location and research subject. The primary data used are in the form of words and actions from the research subject (informants) and written data in the form of documentation [29] [30].

\subsection{Data Collection and Analysis Techniques}

Data collection techniques carried out in this study were interviews. This form of data collection is described by Cresswell [29] and Sugiyono [31] as follows. The interview technique is carried out if the researcher wants to know something in depth from the respondent or informant. The data analysis technique of this research is carried out through three stages, which are often carried out almost simultaneously, namely data reduction, data presentation/ display and making conclusions and verification [30].

\section{Results and Discussion}

\subsection{Result}

This section describes the results of interviews with informants about three parenting styles, namely authoritarian, permissive and democratic parenting styles.

\section{Authoritarian Parenting Type}

To obtain data on the authoritarian parenting style, we have used four questions. First, what are the rules (about studying) that you make for your children at home during the pandemic? Answering this question, the parents of EB replied that he had set rules for learning, but often the children did not obey them. They prioritize time to play rather than study. In fact, the rules made are one of the means of control so that children are disciplined to learn. Parents of SK and OB have relatively the same answer; Children must learn first before playing.

However, when there are assignments from school, children often take the initiative to learn without having to be asked by their parents. Parents of AK and YS are even more assertive in 
saying that at home there are rules that require children to study for a minimum of 2 hours a day. After that, the children can play. Unlike the previous informants, parents of DK and AP said that at home there was no rule that children had to study at certain hours. But as parents, they always remind their children to study. Parents of ErB make learning rules but still give freedom to children to play.

Second, have you ever punished children when they did not do learning activities? Answering this question, parents of EB answered that we once gave sanctions to children who were not disciplined, especially when they played with their cell phones for too long and forgot to study. The sanctions given are in the form of confiscation of cell phones, so that they can focus more on studying. Parents of SK and OB never give sanctions or punishment to their children, because they do not want their children to be stressed. If their children don't study on a certain day parents let them. Because at certain times children take the initiative to learn without being asked by the person. Almost the same as the previous informants' answers, parents of DK never give sanctions to their children. He only reminded and reprimanded his/her son/daughter if he/she did not study.

Third, how do you give attention (love and sympathy) to your children while they are studying at home? Answering this question, the parents of EB answered that he was very busy (as a teacher), so he did not have much time to pay attention to his children. Most of the time with children occurred at night, even though the night was not the right time for studying. Furthermore, the parents of SK and OB answered that they gave attention to their children in the form of words of affection and motivation. They said, our children still have difficulty writing, so we always pay attention to them. DK's parents answered that in the family, they always give attention to the children in the form of words of motivation and affection. Furthermore, the parents of AK, YS and AP stated that they give attention, guide, and provide direction to the children.

Fourth, have you ever forced your children to study? To answer this question, all the informants answered that they never forced the children to study. The reason is that if children are forced, they will most likely do something that is not good for their future development (parents of EB), children will get bored easily (parents of DK). However, we always remind them to learn (parents of AP).

\section{Permissive Type Parenting}

To obtain data on permissive parenting, we used three questions. First, are you "loose" with children when they do self-study at home? Answering this question, the parent of EB states that he gives controlled freedom to the children. Almost the same as parents of EB, parents of SK and OB answered, "we give reasonable freedom to children". But the parents of DK are the opposite. In the family they do not give freedom to children. Parents of AK and YS gave a more moderate answer. They give freedom to the kids but at a certain time. There is time to learn and play. When there is a study schedule, children must study. Furthermore, parents of AP are not independent but always control their children, especially when they are studying.

Second, do you always guide children to study (during the pandemic), until they understand and master what they are learning? Parent of EB replied "We don't give leeway to children, but we give freedom of control. Similarly, parents of SK and OB replied, "We give children reasonable freedom". Then, DK"s parents replied, we don't give freedom to children. Furthermore, parents of AK and YS replied, "We give freedom to children at the right time. At the time to learn they have to study and at the time to play, they can play". Then, the parent of AP replied, "We don't give the widest possible freedom to our children, we always control them, especially when study time has been scheduled". 
Third, do you always agree to every child's wishes, especially when they are studying? Responding to this question, parents of EB, SK, OB, DK gave relatively the same answer, namely they did not always agree to every wish of their children. Similar to the previous informants, parents of AK, YS, and AP stated that they only agreed to the good wishes of the children; requests of children who are considered not good, are not served, while still taking into account the circumstances.

\section{Democratic Type Parenting}

Researchers used four questions to determine the democratic type of parenting. First, Are you motivating your children to learn independently at home during a pandemic, and how do you do it? All informants gave relatively the same answers, namely they often and always motivate their children to learn while studying at home. Parent of EB said, "The motivation that I have given to my children, I think is good, but other people, including my husband, think that I am too harsh in educating children. I realized that I was too busy with my work, so there was not much time to educate the children. Parents of SK and OB stated that we always motivate children to behave well. We want our children not to be abused.

Therefore, we always encourage them with gentle (motivational) words. DK's parents answered, "We always provide motivation (in the form of verbal speech) to the children. We often tell the children, you have to study hard, so that you will become smart and successful in the future." Furthermore, the parents of AK and YS said, "We always motivate children to be enthusiastic and diligent in learning." Similar to other informants, AP's parents often motivate their children to study hard to become champions, get prizes and so on.

Second, how do you carry out learning at home with your children during the pandemic? This question provoked various answers from the informants. The parents of EB said, if I am not at home, my child is usually accompanied by my mother and she guides and teaches my child well. This condition often occurs because I am too busy with my work. Parents of SK and OB said "The way we teach our children is for their teacher to come to the house with textbooks, we and our children open it while paying attention to the learning instructions from the teacher. Next, we guide the child to learn and complete assignments. Parents of DK, AK and YS gave the same answer. They stated that they guide the child when he completes the task given by the teacher. Furthermore, AP's parents answered, we adjust to the circumstances; We do not force children to learn. But when they are given a task by the teacher, we help and guide them to complete it.

Third, how do you appreciate children when they are obedient in learning? All parents of students gave relatively the same answers. They often praise children when they do good things, such as disciplined use of time to study and complete tasks properly. Parents of students experience that the appreciation and praise they give to their children can make their children happier and more enthusiastic in doing learning activities and completing assignments from school (parents of SK, OB and AP). Praise that parents give to their children is usually in the form of words, such as steady, good, cool, etc. (parents from DK)".

Fourth, do you discuss with the children the materials and ways of learning they want? EB's parents replied, my child's awareness to learn is still lacking. So, we haven't had a discussion about how we want to study. Unlike EB parents, SK and OB parents often invite their children to discuss, for example, about studying, napping and playing. Usually, the children carry out what is the result of the discussion or agreement between parents and children. DK ${ }^{\text {ee }}$ s parents also often have discussions with their children when they come home from school and when they have homework and have not finished it. We usually discuss having them finish their homework before playing, or conversely, play first and then finish the homework. AK and YS's 
parents also had discussions with their children while giving them motivation, for example, "if you study hard, you will become an achiever". Furthermore, AP's parents answered, "We often ask children, do you want to study or not? Often our children choose to study.

\subsection{Discussion}

Based on the research results that have been described, the following is a discussion of three parenting styles in the family during the pandemic, namely authoritarian, permissive and democratic parenting styles.

\section{Authoritarian Parenting}

A small number of informants do not use authoritarian parenting in their childcare when they study at home. Most of them apply parenting styles that do not show the characteristics of authoritarian parenting. Authoritarian parenting has characteristics such as using rigid, firm rules, likes to punish, lack of affection, lack of sympathy and so on [22] [23] [24]. On the other hand, the informants always try to give love and attention to children in various forms. This fact is a wellbeing that can reduce stress levels during a pandemic, as experienced by most students and adolescents [32] [33] [34].

If parents do not use authoritarian parenting in educating children, then they actually have made a positive contribution to reducing the negative impact on children's growth and development, both social and cognitive aspects, which are followed by side effects, such as children having difficulty interacting with peers, tending to be alone, insensitive to social situations, feeling anxious and restless, worried when socializing with peers and has a low conscience [22].

\section{Permissive Parenting}

All parents interviewed did not show a permissive parenting style in teaching their children at home. They exercise more control over their children's learning. This occurs because during the pandemic, parents "returned" to act as pedagogues for their children. This role is no longer facultative, as was the case with many parents before the pandemic, but a responsibility that must be carried out. As a responsibility, parents must be able to design children's learning activities (make a study schedule), create conducive learning conditions, accompany children's learning, facilitate learning and solve learning problems with children [7] [35]. Thus, parents (during the pandemic) take on the role of teachers in schools. He must provide time to assist children in learning and guide them to solve learning problems they face, both because of the demands of the situation (e.g. government instructions) and the calling of the soul attached to the duties, functions and responsibilities of parents in the family [5].

\section{Democratic Parenting}

Democratic parenting is the type of parenting that is most widely applied by informants. They provide opportunities for children to grow into independent, inclusive individuals, accepting things from another point of view. The type of democratic parenting they do opens up opportunities for children to discuss everything, especially those related to studying, playing, and using mobile phones. In fact, parents can use their power to determine and decide many things without involving their children. By using the democratic type of parenting, parents want their children to grow and develop optimally and proportionally in many aspects of development, such as cognitive, social, moral, etc. [3] [17].

The results of this study strengthen and confirm previous research. Research conducted by Rohan, Mushafanah and Rahmawati [36] has revealed that the dominant parenting patterns 
carried out by parents in the family during the Covid-19 pandemic were democratic, authoritarian, and permissive parenting, respectively. That means, the democratic type of parenting is the best parenting pattern applied by parents during the pandemic and online learning, where children are given the opportunity to learn from home.

Democratic parenting not only has a positive impact on social aspects (adjustment for good social interactions) and psychological (reducing stress levels and emotional closeness between parents and children), but also on academic aspects (students get good learning outcomes in school [37], while the type of authoritarian parenting tends not to have a positive effect on students' learning achievement [38]. Therefore, parents at SDK Sta. Theresia Parepei, Manado are individuals who have educational responsibilities in the family. They have played a role as pedagogues: knowing good practice in education and understanding the impacts of every decision and action they take on their children.

\section{Conclusion}

Based on the results and discussion of the study, there are three points that can be described as conclusions. First, most of the parents (three parents of the students) have implemented democratic type of parenting and two parents carried out authoritarian type of parenting. Second, at the third-grade elementary school level, all parents believe that their children do not yet have the basics and habits of independent study. Therefore, neither parent uses permissive parenting. All of them do not give absolute freedom to their children to determine learning strategies independently. Third, the implementation of learning during the Covid-19 pandemic encourages parents (especially parents with children at the elementary school level) to reinvention their pedagogical role, so that they wisely manage time to educate children on the one hand and carry out careers on the other.

Based on this conclusion, there are several suggestions that can be put forward. First, for future research: 1) it is necessary to measure the effectiveness of each type of parenting on changes in student development, both cognitive, social and skill aspects; 2) it is necessary to conduct research on parents who have children at a higher level than elementary school; 3 ) it is necessary to increase the research sample (both the number of subjects and the level of education) so that the results are more general. Second, the implementation of education. In the future, parents need to be continuously empowered, both in terms of pedagogy and technical skills related to the use of internet technology for children's learning purposes.

\section{References}

[1] Dhawan, S. Online Learning: A Panacea in the Time of Covid-19 Crisis. Journal of Educational Technology Systems, Vol. 49, Iss 1,pp.6-22, 2020.

[2] Dapiyanta, "Pendidikan Dalam Keluarga: Komunikasi Antar Generasi". Dalam Midun, H \& Mite, MB (Eds.). Peran Keluarga dan Pendidikan Di Era Globalisasi.Malang: Dioma, pp. 29-40, 2016.

[3] Sudiapermana, E., Muslikhah, M., \& Rokhman, N. The Relationship Of Family Life Education And Children "es Learning Achievement. Journal of Educational Social Studies, Vol. 29, Iss 1, pp. 1-8, 2020. https://journal.unnes.ac.id/sju/index .php/jess/article/view/38341.

[4] Midun, H. "Pendidikan Karakter Dalam Keluarga Sebagai Basis Pembentukan Moralitas Anak Di Era Globalisasi”. In Midun, H \& Mite, MB (Eds.). Peran Keluarga dan Pendidikan Di Era Globalisasi, Malang: Dioma, pp. 56-80, 2016. 
[5] Susilowati, E."Peranan Keluarga Menghadapi Pandemi Covid-19 Di Indonesia”. Dalam Fahrudin, et al. (eds.), Covid-19 Pandemi DalamBanyak Wajah. Jakarta: PT Rajagrafindo Persada, pp. 111-117, 2021.

[6] Jannah, R \& Santoso, H. Tingkat Stres Mahasiswa Mengikuti Pembelajaran Daring pada Masa Pandemi Covid-19”, Jurnal Riset dan Pengabdian Masyarakat, Vol.1, Iss 1, pp 130-146, 2021.

[7] Midun, H. "Produktivitas Pendidikan Masa Pandemi Covid 19". In Midun, H \& Tapung, MM. (Eds.). Pemberdayaan Sumber Daya Era Dan Pasca Pandemi Covid 19. Malang: Seribu Bintang, pp. 83$122,2021$.

[8] APO. Productivity In Higher Education, Research Insights For Universities And Governments In Asia. Tokyo: Asian Productivity Organization, 2017.

[9] Jamal, S. Analisis Kesiapan Pembelajaran E-Learning Saat Pandemi Covid-19 Di SMK Negeri 1 Tambelangan. Jurnal Nalar Pendidikan, Vol. 8, Iss 1, pp. 16-22, 2020.

[10] Jalal, M. Kesiapan Guru Menghadapi Pembelajaran Jarak Jauh Di Masa Covid-19. SMART KIDS. Jurnal Pendidikan Islam Anak Usia Dini, Vol. 2, Iss 1, 35- 40, 2020.

[11] Novitasari, D. \& Asbari, M. Peran Kesiapan untuk Berubah terhadap Kinerja Guru di Masa Pandemi Covid-19. Journal of Industrial Engineering \& Management Research, Vol. 1, Iss 2, pp.219-237, 2020.

[12] Allen, JV. Developing digital literacy skills through guided reading. Florida Read. Journal, Vol. 51, Iss 1, pp. 16-20, 2016.

[13] Lankshear, C \& Knobel, M. Digital literacy and digital literacies: Policy, pedagogy and research consideration for education. Nord. Journal Digital Literacy, pp. 8-20, 2016.

[14] Aman, J, Akram,MB, Mas'udah,S, Saud, M \& Manj, YN. Parental Involvement For Better Education: The Relationship Between Parental Awareness, Emotional Support, and Children"s Academic Achievement At Secondary Level. Masyarakat, Kebudayaan dan Politik, Vol. 32, Iss 4, pp. 334-34, 2019. https://e journal.unair.ac.id/MKP/article/view/14404

[15] Soekirman. Ilmu Gizi dan Aplikasinya: untuk Keluarga dan Masyarakat. Jakarta: Dirjen Dikti, Departemen Pendidikan Nasional, 2000.

[16] Christner N, Essler S, Hazzam A, Paulus M. Children"s psychological well-being and problem behavior during the COVID-19 pandemic: An online study during the lockdown period in Germany. PLoS ONE, Vol. 16, Iss 6, 2021. https://doi.org/10.1371/journal.pone .0253473.

[17] Xu, Y \& Wu, Q. Parenting stress and risk of child maltreatment during the COVID-19 pandemic: A family stress theory-informed perspective. Developmental Child Welfare, Vol. 2, Iss 3, 180-196, 2021.https://doi.org/10.1177/2516103220 967937 .

[18] Wu, CST, Fowler, C, Lam, WYY, Wong, HT, Wong, CHM, Loke, AY. Parenting approaches and digital technology use of preschool age children in a Chinese community. Italian Journal of Pediatrics,Vol.40, pp. 1-8, 2014. https://doi.org/10.1186/1824-7288-40-44.

[19] Killing-Bunga, BN, Margiani, K \& Killing, IY. Parenting Research in Indonesia: What We Have Done So Far. Buletin Psikologi, Vol. 28, Iss 1, 59-71, 2020.https://jurnal.ugm.ac.id/buletinpsik ologi/article/view/51578/pdf.

[20] Reid, CAY, Roberts, LD, Roberts, CM \& Piek, JP. Towards a Model of Contemporary Parenting: The Parenting Behaviours and Dimensions Questionnaire. PLOS ONE, Vol. 10, Iss 6, 2015. https://doi.org/10.1371/journal.pone .0114179

[21] Leijten, P, Gardner, F, Melendez Torres, GJ, Knerr, W, Overbeek, G. Parenting Behaviors that Shape Child Compliance: A multilevel meta-analysis. PLOS ONE, Vol. 13, Iss 10, pp. 1-15, 2018. https://doi.org/10.1371/journal.pone .0204929.

[22] Anisah, AS. Pola Asuh Orang Tua dan Implikasinya terhadap Pembentukan Karakter Anak. Jurnal Pendidikan Universitas Garut, Vol. 5, Iss 1, 2011.

[23] Sunarty, K \& Dirawan, GD. Development Parenting Model to Increase the Independence of Children. International Education Studies, Vol. 8, Iss 10, pp. 107-113. 2015. Doi: 10.5539/ies.v8n10p107.

[24] Boediman, LM \& Desmawati, S. The Relationship between Parenting Style and Children "s Emotional Development among Indonesian Population. Mind Set, Vol. 10, Iss 1, pp.17-24, 2019. http://journal.univpancasila.ac.id/index.php/mindset/article/view/735/4 81. 
[25] Leijten, P, Gardner, F, Melendez Torres, GJ, Knerr, W, Overbeek, G. Parenting behaviors that shape child compliance: A multilevel meta-analysis (Research Article). PLOS ONE, Vol. 13, Iss 10. 115,2018.https://doi.org/10.1371/journal.pon e.0204929.

[26] Reid, CAY, Roberts, LD, Roberts, CM \& Piek, JP. Towards a Model of Contemporary Parenting: The Parenting Behaviours and Dimensions Questionnaire. PLOS ONE, Vol.10, Iss 6, 2015. https://doi.org/10.1371/journal.pone.0114179.

[27] Burgess, S \& Sievertsen, HH. "Schools, Skills, and Learning: The Impact of Covid-19 on Education", https://voxeu.org/article/impact covid-19-education, accessed on 26 July 2021.

[28] Midun, H. "Strategi Optimalisasi Pembelajaran Era Dan Pasca Pandemi Covid-19”. In Regus, M \& Yuliantari, AP, Tantangan Pendidikan Pada Masa Pandemi Covid-19. Ruteng: Unika Santu Paulus, pp. 41-62, 2020.

[29] Cresswell, JW. Research Design Qualitative, Quantitative, and Mixed Methods Approaches (Third Edition). London: Sage Publication, Inc., 2009.

[30] Miles, MB, Huberman, AM \& Saldana, J. Qualitative Data Analysis: A Sourcebook of New Methods. California: SAGE Publications, 2014.

[31] Sugiyono. Metode Penelitian Pendidikan-Pendekatan Kuantitatif, Kualitatif, dan R\&D. Bandung: Alfabeta, 2013.

[32] Fauziyyah, R, Awinda,RC, \& Besral, B..’Dampak Pembelajaran Jarak Jauh terhadap Tingkat Stres dan Kecemasan Mahasiswa selama Pandemi COVID-19. Jurnal Bikfokes: Biostatistik, Kependudukan, dan Informasi Kesehatan, Vol. 1, Iss 2, pp. 113- 123, 2021

[33] Harsono, FH.. "Survei KPAI: Belajar di Rumah Selama COVID 19 Bikin Anak Stres dan Lelah", https://www.liputan6.com/health/re ad/4251622/survei-kpai-belajar-di rumah-selama-covid-19bikinanak-stres-dan-lelah, diakses 8 Mei 2021.

[34] Jannah, R \& Santoso, H.’Tingkat Stres Mahasiswa Mengikuti Pembelajaran Daring pada Masa Pandemi Covid-19”, Jurnal Riset dan Pengabdian Masyarakat,Vol. 1, Iss.1, 130-146, 2021

[35] Cahyati, N \& Kusumah, R. Peran Orang Tua Dalam Menerapkan Pembelajaran Di Rumah Saat Pandemi Covid 19. Jurnal Golden Age, Vol.4 Iss. 1, pp. 152-159, 2020.

[36] Rohana, T, Mushafanah, Q \& Rahmawati, I. Analisis Pola Asuh Orang Tua Terhadap Prestasi Siswa Kelas V SD. Jurnal Ilmiah Pendidikan Profesi Guru. Vol. 3, Iss 2, 2020.

[37] Seng, NL, Hanafi, Z \& Taslikhan, M. Parenting Styles and Academic Achievement. Scholars Journal of Arts, Humanities and Social Sciences, Vol. 4, Iss.3A, pp. 193-200, 2016. http://repository.unitomo.ac.id/113/1/Parenting\%20 Styles\%20and\%20 Academic\%20 Achievement.pdf.

[38] Syuharyoso, NFA. Hubungan Pola Asuh Demokratis terhadap Kemampuan Berbahasa Anak Kelompok B di TK „Aisyiyah Gonilan Kartasura Kabupaten Sukoharjo.Tajida, Vol. 13, Iss. 2,pp.316-147, 2015. http://journals.ums.ac.id/index.php/tajdida/article/view/1883 